\title{
Dissolution of Manganese from Polymetallic Material Using Sulfuric-Oxalic Acid Medium
}

\author{
Mona N. El Hazek1,2, Azza A. Gabr2,3 \\ ${ }^{1}$ Nuclear Materials Authority, El Maadi, Cairo, Egypt \\ ${ }^{2}$ Chemistry Department, Faculty of Science, Jazan University, Jazan, Saudi Arabia \\ ${ }^{3}$ Chemistry Department, Faculty of Science, Aswan University, Aswan, Egypt \\ Email: monaelhazek@hotmail.com
}

Received 19 March 2016; accepted 16 May 2016; published 19 May 2016

Copyright (C) 2016 by authors and Scientific Research Publishing Inc.

This work is licensed under the Creative Commons Attribution-Non Commercial International License (CC BY-NC).

http://creativecommons.org/licenses/by-nc/4.0/

(c) (1) (9) Open Access

\begin{abstract}
Sedimentary rocks have been found to host several Mn minerals in addition to some economic metal values. Besides recoverable $\mathrm{Al}$ occurring as gibbsite mineral, the latter include $\mathrm{Cu}, \mathrm{Zn}, \mathrm{Co}, \mathrm{Ni}$, $U$ as well as rare earth elements. In this work, the ore material was subjected to sulfuric acid leaching in the presence of oxalic acid as a reductant to maximize the extraction of Mn. The optimum leaching conditions to achieve almost complete leaching efficiency of Mn with Fe dissolution not exceeding $13 \%$ involved $0.5 \mathrm{M}$ sulfuric acid and $0.25 \mathrm{M}$ oxalic acid in a solid/liquid ratio of $1 / 15$ at $85^{\circ} \mathrm{C}$ for $105 \mathrm{~min}$ using an ore size of $-150 \mu \mathrm{m}$. The leaching behavior of the associated interesting metal values $(\mathrm{Al}, \mathrm{Cu}$ and $\mathrm{Zn})$ has also been investigated.
\end{abstract}

\section{Keywords}

Polymetallic Mn Material, Oxalic-Sulfuric Acid, Agitation Dissolution

\section{Introduction}

Various hydrometallurgical methods have been suggested in the literature for the treatment of low grade manganese ores. Such ores can be treated either by reduction roasting followed by acid leaching [1] or directly by reductive acid leaching using different reducing agents. To realize the latter, several procedures have been suggested; namely mixed methanol-sulfuric solution [2], coke [3], non aqueous dimethyl sulfoxide [4], iron(П) sulphate [5], aqueous sulfur dioxide [6]-[8], sulfuric acid and hydrogen peroxide [9] [10], hydrochloric acid and nickel matte [11], hydrochloric acid and pyrite [12] [13]. The latter authors have pointed out that the chloride ion at high concentrations was responsible for the reduction of higher valence state oxides. On the other hand, 
leaching processes in basic media involve the use of ammonium sulfite as reductant [14], in addition to several patented leaching processes [15]-[17]. Recently, Sahoo et al. (2001) have been able to leach Mn-Iron low grade ore assaying $24.7 \% \mathrm{Mn}$ and $28.4 \%$ Fe using sulfuric acid in the presence of oxalic acid as a reductant.

In Egypt, sediments composed of shale, siltstone, clay, ferruginous sandstone, calcareous sandstone and feldspathic sandstone [18]-[20]. This polymetallic ore is associated with varying amounts of $\mathrm{U}, \mathrm{Mn}, \mathrm{Zn}, \mathrm{Cu}, \mathrm{Co}$, $\mathrm{Ni}, \mathrm{REE}, \mathrm{V}$, etc.

Several local leaching studies have actually been performed upon the Mn ores with different constituents and grades of the economic metal values. These studies include those of Amer [21] [22], El Hazek et al. [23] and Lasheen et al. [24]. Thus, Amer [21] [22] investigated the leaching characteristics of $\mathrm{U}, \mathrm{Cu}$ and $\mathrm{Mn}$ from a similar ore material by pug leaching using $\mathrm{H}_{2} \mathrm{SO}_{4}$ acid-as well as using $\mathrm{Fe}_{2}\left(\mathrm{SO}_{4}\right)_{3}$ or $\mathrm{FeCl}_{3}$ as lixiviants. El Hazek et al. [23] investigated manganese leaching from a low-grade ore (about $11 \% \mathrm{MnO}$ ) from Sinai using hydrochloric acid in the presence of hydrogen peroxide as a reducing agent. On the other hand, Lasheen et al. [24] have also studied the recovery of manganese and some associated metal values from a more rich ore material (48.4\% $\mathrm{MnO})$ using nitric acid medium in presence of molasses as reductant.

The present work has also been oriented towards studying the acid leaching characteristics of Mn and some of the associated metal values by using oxalic acid as a reductant. The leaching characteristics of this ore material have previously been studied using sulfuric acid only in a manner not to allow Mn leaching. Besides Mn, the studied metal values included $\mathrm{Al}, \mathrm{Cu}$ and $\mathrm{Zn}$. In the performed leaching experiments, the relevant parameters were so chosen in order to keep iron dissolution — which highly contaminates Mn products— to the least possible amount.

\section{Experimental}

\subsection{Analytical Procedures}

The major oxides of the working sample were determined using the rapid silicate analysis method of Shapiro and Brannock [25]. For the analysis of $\mathrm{Cu}, \mathrm{Zn}, \mathrm{Co}$ and Ni the atomic absorption technique was adopted using a Unicam Atomic Absorption Spectrometer model 969 at the following wavelengths 222.60, 307.60, 243.70 and $305.10 \mathrm{~nm}$ respectively [26]. Al and Mn were detected by AAS at the wavelengths 309.30 and $403.10 \mathrm{~nm}$ respectively [26]. On the other hand, an oxidimetric titration method against ammonium metavanadate was used for $U$ analysis in the presence of diphenylamine sulfonate indicator. Prior to titration, proper reduction of $U$ was performed using ammonium ferrous sulfate [27].

To define the mineralogical composition of the working ore material, the collected study sample was subjected to X-ray diffraction analysis. For this purpose, a Philips X-ray diffractometer, model PW 223/20 was used where the copper tube was operated at $40 \mathrm{kV}$ and $20 \mathrm{~mA}$.

\subsection{Leaching Procedure}

Different leaching conditions were studied to attain the maximum possible leaching efficiency of the studied metal values. These conditions include the reagent concentration, time, temperature, ore sample to reagent ratio and the ore grain size. Leaching was carried out in a well-stirred 3 necked round flask fitted with a thermometer and condenser. The leaching efficiency of each metal value was calculated from the analysis of the pregnant leach solution after filtering and washing the slurry.

\section{Results and Discussion}

\subsection{Solid Characterization}

From the obtained analyses, it was found that the ore material assays about $27 \% \mathrm{Al}_{2} \mathrm{O}_{3}$ together with other metal contents of $8.4 \% \mathrm{MnO}$ mainly as pyrolusite $\left(\mathrm{MnO}_{2}\right), 3.4 \% \mathrm{ZnO}$ in addition to $1900 \mathrm{ppm} \mathrm{Cu}, 1000 \mathrm{ppm} \mathrm{Co}, 730$ ppm Ni, and 400 ppm U besides a total rare earth elements (REE) content of 6200 ppm (Table 1).

On the other hand, the obtained diffractogram was properly interpreted using standard diffraction mineral patterns [28] and revealed the presence of several minerals such as gibbsite, dolomite together with a variety of manganese minerals as cryptomelane $\mathrm{KMn}_{8} \mathrm{O}_{16}$, chalcophanite $\mathrm{ZnMn}_{3} \mathrm{O}_{7} \cdot 3 \mathrm{H}_{2} \mathrm{O}$, pyrolusite $\mathrm{MnO}_{2}$ and crednerite $\mathrm{CuMnO}_{2} \mathrm{O}_{4}$. In the light of this mineral composition, it was possible by proper calculation of the obtained 
chemical analysis, together with some dissolution tests, to infer the mineralogical composition (mode) shown in Table 2. It is notable that gibbsite $\left[\mathrm{Al}(\mathrm{OH})_{3}\right]$, representing an important mineral of $\mathrm{Al}$, amounted to $33 \%$ while dolomite—which would consume acid—assays about $21 \%$.

\subsection{Study of Leaching Parameters}

\subsubsection{Effect of Sulfuric Acid Concentration}

To study the effect of sulfuric acid concentration on the leaching efficiency of Mn and other associated metal values, a number of preliminary leaching experiments were performed using different acid concentrations ranging from 0.2 to $1 \mathrm{M}$. In these experiments, the other leaching conditions were fixed at $0.24 \mathrm{M}$ oxalic acid, $2 \mathrm{~h}$ agitation time at $90^{\circ} \mathrm{C}$ with a solid/liquid ratio (pulp density) of $1 / 15$ using $-150 \mu \mathrm{m}$ ore grain size. From the results shown in Table 3, it is clear that the amount of input acid, which depends in turn upon its concentration

\section{Table 1. Chemical composition of Abu Zeneima gibbsite ore material.}

\begin{tabular}{cccc}
\hline Major constituent & Wt., \% & Trace constituent & Conc., ppm \\
\hline $\mathrm{SiO}_{2}$ & 13.50 & $\sum \mathrm{REE}$ & 6200 \\
$\mathrm{Al}_{2} \mathrm{O}_{3}{ }^{*}$ & 27.00 & $\mathrm{Cu}$ & 1900 \\
$\mathrm{Fe}_{2} \mathrm{O}_{3}$ & 12.30 & $\mathrm{Co}$ & 1000 \\
$\mathrm{CaO}$ & 6.53 & $\mathrm{Ni}$ & 730 \\
$\mathrm{MgO}$ & 4.66 & $\mathrm{U}$ & 400 \\
$\mathrm{Na}_{2} \mathrm{O}$ & 1.04 & & \\
$\mathrm{~K}_{2} \mathrm{O}$ & 1.55 & & \\
$\mathrm{MnO}$ & 8.40 & & \\
$\mathrm{ZnO}$ & 3.40 & & \\
$\mathrm{H}_{2} \mathrm{O}^{\text {(humidity) }}$ & 1.81 & & \\
$\mathrm{~L} \mathrm{O} \mathrm{I}{ }^{* *}$ & 21.30 & & \\
Total & 101.49 & & \\
\hline
\end{tabular}

*Total alumina corresponding to gibbsite and clay minerals; ${ }^{* *} \mathrm{LOI}$ includes $\mathrm{H}_{2} \mathrm{O}^{\text {(crystalline) }}$ and $\mathrm{CO}_{2}$.

Table 2. Estimated mineralogical composition (mode) of Abu Zeneima gibbsite ore material.

\begin{tabular}{cc}
\hline Mineral/Oxide & Wt.,\% \\
\hline Gibbsite & 33.00 \\
Dolomite & 21.45 \\
$\mathrm{Fe}_{2} \mathrm{O}_{3}{ }^{*}$ & 12.30 \\
$\mathrm{MnO}^{* *}$ & 8.40 \\
$\mathrm{ZnO}^{* * *}$ & 3.40 \\
Qz, Silicates & 21.49 \\
Total & 100.04 \\
\hline
\end{tabular}

"Equivalent for both goethite and hematite; ${ }^{* *}$ Equivalent for the detected Mn minerals; ${ }^{* * *}$ Present in chalcophanite.

Table 3. Effect of sulfuric acid concentration upon leaching efficiency of Mn and associated metal values ( $0.24 \mathrm{M}$ oxalic acid, $2 \mathrm{~h}, \mathrm{~S} / \mathrm{L}$ ratio $1 / 15,90^{\circ} \mathrm{C},-150 \mu \mathrm{m}$ grain size).

\begin{tabular}{cccccc}
\hline \multirow{2}{*}{ Sulfuric acid conc., $M$} & \multicolumn{5}{c}{ Leaching Efficiency, \% } \\
\cline { 2 - 6 } & $\mathrm{Al}^{*}$ & $\mathrm{Mn}$ & $\mathrm{Zn}$ & $\mathrm{Cu}$ & $\mathrm{Fe}$ \\
\hline 0.2 & 14.3 & 74.3 & 73.2 & 76.4 & 11.9 \\
0.5 & 36.7 & 98.2 & 94.1 & 92.1 & 14.7 \\
0.8 & 54.0 & 98.7 & 91.2 & 88.5 & 16.9 \\
1.0 & 72.6 & 98.7 & 92.0 & 87.3 & 20.3 \\
\hline
\end{tabular}

$\mathrm{Al}^{*}$ calculated as gibbsite. 
and the solid/liquid ratio, has a direct influence upon the dissolution of the interesting metal values specially $\mathrm{Al}$ and Fe. However, at only $0.5 \mathrm{M}$ acid concentration, the leaching efficiencies of the 3 working metal values i.e. $\mathrm{Mn}, \mathrm{Zn}$ and $\mathrm{Cu}$ attained about 98\%, 94\% and 92\% respectively. As a matter of fact, the leaching efficiencies of $\mathrm{Zn}$ and $\mathrm{Cu}$ are always comparable to that of $\mathrm{Mn}$ due to their existance in its two mineral species detected by XRD; namely $\mathrm{Zn}$ and $\mathrm{Mn}$ in chalcophanite and $\mathrm{Cu}$ and $\mathrm{Mn}$ in crednerite. However, in case of $\mathrm{Cu}$, it is noticed that its leaching efficiency slightly decreased as acid concentration increased from 0.5 to $1 \mathrm{M}$; a matter which might be due to hydrolysis or else to partial reduction by oxalic acid to its monovalent state $\left(\mathrm{Cu}^{+}\right)$.

On using sulfuric acid without oxalic acid, the Mn leaching efficiency at the three acidities of 1,2 and $4 \mathrm{M}$ was only $1.5 \%, 1.9 \%$ and $2.5 \%$ respectively, a matter which indicates the necessity of using a reducing agent.

It is interesting to mention that a leaching experiment using concentrated $\mathrm{HCl}$ with a solid/liquid ratio of 1/3 at $100^{\circ} \mathrm{C}$ for $4 \mathrm{~h}$ resulted in almost complete leaching of $\mathrm{Mn}(99.7 \%)$ together with $96.5 \% \mathrm{Cu}$, complete leaching of $\mathrm{Al}$ in the gibbsite mineral as well as over $85 \%$ of $\mathrm{Zn}$. In this regard, it is also significant to mention that $2 \mathrm{M}$ $\mathrm{HCl}$ at $90^{\circ} \mathrm{C}$ for $2 \mathrm{~h}$ with a solid/liquid ratio of $1 / 12$ gives $67 \% \mathrm{Mn}$ leaching. This is because the chloride ions at such high concentrations are responsible for the reduction of higher valence state oxides.

Finally, it is interesting to indicate herein that $\mathrm{Mn}$ leaching is due to the reduction of its dioxide by the added oxalic acid. According to Ehrlich (1980), $\mathrm{MnO}_{2}$ reduction by oxalic acid in acid medium may be represented by the following reaction:

$$
\mathrm{MnO}_{2}+\mathrm{HOOC}-\mathrm{COOH}+2 \mathrm{H}^{+} \rightarrow \mathrm{Mn}^{2+}+2 \mathrm{CO}_{2}+2 \mathrm{H}_{2} \mathrm{O}
$$

Regarding the acid amount required for reacting with all the basic constituents of the working ore material, an acid consumption test was performed using $250 \mathrm{~g}$ ore in $4 \mathrm{M} \mathrm{H}_{2} \mathrm{SO}_{4}$ with a $\mathrm{S} / \mathrm{L}$ ratio of $1 / 3$ at $80^{\circ} \mathrm{C}$ for $4 \mathrm{~h}$. Analysis of the remaining acid after proper complexing the hydrolyzed cations revealed that the acid consumption attains about $750 \mathrm{Kg} / \mathrm{t}$ ore. Calculation of the input acid concentration of $0.5 \mathrm{M}$ in a S/L ratio of 1/15 would indicate that the input acid amount is just the necessary amount for reacting with the basic ore components under the mentioned conditions.

\subsubsection{Effect of Oxalic Acid Concentration}

To study the amount of oxalic acid that would be responsible for the reduction of $\mathrm{Mn}$ in the working ore materi$\mathrm{al}$, a set of leaching experiments was performed using different oxalic acid concentrations ranging from 0 to 0.40 $\mathrm{M}$. The other leaching conditions were fixed at $2 \mathrm{~h}$ agitation time at $90^{\circ} \mathrm{C}$ with a solid/liquid ratio (pulp density) of $1 / 15$ and using $-150 \mu \mathrm{m}$ ore grain size. From the results shown in Table 4, it is clear that addition of oxalic acid is necessary to improve the leaching efficiencies of $\mathrm{Mn}$ and the other associated metal values. Thus, at 0.24 $\mathrm{M}$ oxalic acid concentration, almost complete Mn leaching was achieved besides about $94 \%$ of $\mathrm{Zn}$ and $92 \%$ of $\mathrm{Cu}$. However increasing the oxalic concentration to $0.40 \mathrm{M}$ has not led to any perceptible improvement in the leaching efficiencies of $\mathrm{Zn}$ and $\mathrm{Cu}$.

\subsubsection{Effect of Leaching Time}

For studying the effect of the leaching time, another series of experiments was made using $0.5 \mathrm{M}$ sulfuric acid and $0.24 \mathrm{M}$ oxalic acid at $90^{\circ} \mathrm{C}$ with a solid/liquid ratio (pulp density) of $1 / 15$ using $-150 \mu \mathrm{m}$ ore grain size. From the results shown in Table 5, it is clear that at leaching time of 105 min, sufficiently high leaching efficiencies of $\mathrm{Mn}, \mathrm{Zn}$ and $\mathrm{Cu}$ of about 98\%, 95\% and 92\% have been realized. However, extension of leaching time to 120 min has increased the undesirable Fe leaching efficiency to $14.7 \%$ compared to $12.7 \%$ at 105 min.

\subsubsection{Effect of Leaching Temperature}

The influence of temperature upon the leaching efficiency of Mn and other associated metal values was studied through a series of experiments at temperatures ranging from $25^{\circ} \mathrm{C}$ to $100^{\circ} \mathrm{C}$. The other leaching conditions were fixed at $0.5 \mathrm{M}$ sulfuric acid and $0.24 \mathrm{M}$ oxalic acid for $2 \mathrm{~h}$ agitation time in a solid/liquid ratio (pulp density) of $1 / 15$ and using $-150 \mu \mathrm{m}$ ore grain size. From the results shown in Table 6, it is clear that almost complete Mn leaching was achieved at $90^{\circ} \mathrm{C}(98.2 \%)$. Also both $\mathrm{Zn}$ and $\mathrm{Cu}$ have attained high leaching efficiencies of $94.1 \%$ and $92.1 \%$ respectively and raising the leaching temperature to more than $90^{\circ} \mathrm{C}$ didn't improve their leach ability. On the other hand, the leaching temperature has great influence on dissolution of the undesirable Fe where its leaching efficiency has increased from $14.7 \%$ to $18.0 \%$ when the leaching temperature was raised from $90^{\circ} \mathrm{C}$ to $100^{\circ} \mathrm{C}$. 
Table 4. Effect of oxalic acid concentration upon leaching efficiency of $\mathrm{Mn}$ and associated metal values ( $0.5 \mathrm{M}$ sulfuric acid, $2 \mathrm{~h}, 90^{\circ} \mathrm{C}, \mathrm{S} / \mathrm{L}$ ratio $1 / 15,-150 \mu \mathrm{m}$ grain size).

\begin{tabular}{cccccc}
\hline \multirow{2}{*}{ Oxalic acid conc., $\mathrm{M}$} & \multicolumn{5}{c}{ Leaching Efficiency, \% } \\
\cline { 2 - 6 } & $\mathrm{Al}^{*}$ & $\mathrm{Mn}$ & $\mathrm{Zn}$ & $\mathrm{Cu}$ & $\mathrm{Fe}$ \\
\hline 0.00 & 12.5 & 1.5 & 51.0 & 64.2 & 9.8 \\
0.08 & 21.8 & 68.5 & 67.0 & 72.1 & 10.5 \\
0.16 & 28.2 & 74.4 & 83.0 & 81.1 & 11.2 \\
0.24 & 36.7 & 98.2 & 94.1 & 92.1 & 14.7 \\
0.32 & 35.9 & 99.5 & 94.2 & 92.8 & 14.6 \\
0.40 & 36.5 & 98.5 & 93.6 & 93.2 & 15.1 \\
\hline
\end{tabular}

$\mathrm{Al}^{*}$ calculated as gibbsite.

Table 5. Effect of time upon leaching efficiency of Mn and associated metal values $(0.5 \mathrm{M}$ sulfuric acid and $0.24 \mathrm{M}$ oxalic acid, $90^{\circ} \mathrm{C}, \mathrm{S} / \mathrm{L}$ ratio $1 / 15,-150 \mu \mathrm{m}$ grain size).

\begin{tabular}{cccccc}
\hline \multirow{2}{*}{ Time, $\min$} & \multicolumn{5}{c}{ Leaching Efficiency, \% } \\
\cline { 2 - 6 } & $\mathrm{Al}^{*}$ & $\mathrm{Mn}$ & $\mathrm{Zn}$ & $\mathrm{Cu}$ & $\mathrm{Fe}$ \\
\hline 30 & 12.7 & 61.5 & 60.5 & 61.2 & 9.5 \\
60 & 20.4 & 78.2 & 71.0 & 73.7 & 11.2 \\
90 & 29.8 & 91.4 & 88.0 & 87.2 & 12.1 \\
105 & 36.0 & 98.2 & 94.5 & 92.2 & 12.7 \\
120 & 36.7 & 98.2 & 94.1 & 92.1 & 14.7 \\
\hline
\end{tabular}

$\mathrm{Al}^{*}$ calculated as gibbsite.

Table 6. Effect of temperature upon leaching efficiency of Mn and associated metal values ( $0.5 \mathrm{M}$ sulfuric acid and $0.24 \mathrm{M}$ oxalic acid, $2 \mathrm{~h}, \mathrm{~S} / \mathrm{L}$ ratio $1 / 15,-150 \mu \mathrm{m}$ grain size).

\begin{tabular}{cccccc}
\hline & \multicolumn{5}{c}{ Leaching Efficiency, \% } \\
\cline { 2 - 6 } Temp., ${ }^{\circ} \mathrm{C}$ & $\mathrm{Al}^{*}$ & $\mathrm{Mn}$ & $\mathrm{Zn}$ & $\mathrm{Cu}$ & $\mathrm{Fe}$ \\
\hline 50 & 8.5 & 64.0 & 47.2 & 41.9 & 3.6 \\
75 & 11.2 & 77.4 & 71.2 & 72.8 & 8.2 \\
90 & 23.5 & 89.7 & 86.5 & 90.1 & 10.9 \\
100 & 36.7 & 98.2 & 94.1 & 92.1 & 14.7 \\
\hline
\end{tabular}

$\mathrm{Al}^{*}$ calculated as gibbsite.

\subsubsection{Effect of Solid/Liquid Ratio}

Working at the same acid concentrations but varying the solid/liquid ratio could provide for improved metal leaching through the increased amount of the input acid. The effect of solid/liquid ratio was then studied using $0.5 \mathrm{M}$ sulfuric acid and $0.24 \mathrm{M}$ oxalic acid for $2 \mathrm{~h}$ at $90^{\circ} \mathrm{C}$ and using $-150 \mu \mathrm{m}$ ore grain size. The obtained data are tabulated in Table 7 and demonstrate that decreasing the pulp density to $1 / 15$ was beneficial for the extraction of the studied metal values. Thus as the $\mathrm{S} / \mathrm{L}$ ratio is decreased from $1 / 5$ to $1 / 15$, the $\mathrm{Mn}$ leaching efficiency increased from $80.2 \%$ to $98.2 \%$ whereas the leaching efficiencies of $\mathrm{Zn}$ and $\mathrm{Cu}$ increased from $77.6 \%$ to $94.1 \%$ and from $79.4 \%$ to $92.1 \%$ respectively.

\subsubsection{Effect of Ore Grain Size}

Finally, the effect of the grain size of the study ore material was studied in the range of -250 down to $-88 \mu \mathrm{m}$ while fixing the other leaching conditions at $0.5 \mathrm{M}$ sulfuric acid and $0.24 \mathrm{M}$ oxalic acid for $2 \mathrm{~h}$ at $90^{\circ} \mathrm{C}$ in the $\mathrm{S} / \mathrm{L}$ ratio of $1 / 15$. The obtained results shown in Table 8, indicate only a slight improvement in the leaching efficiencies of all the metal values with finer grain sizes. As a matter of fact, increased ore grinding generally represents excessive energy consumption and having high leaching efficiencies in this work at relatively coarse size would realize important cost reduction. 
Table 7. Effect of solid/liquid ratio upon leaching efficiency of Mn and associated metal values (0.5 M sulfuric acid and 0.24 Moxalic acid, $2 \mathrm{~h}, 90^{\circ} \mathrm{C},-150 \mu \mathrm{m}$ grain size).

\begin{tabular}{ccccccc}
\hline \multirow{2}{*}{ Solid/Liquid Ratio } & \multicolumn{5}{c}{ Leaching Efficiency, \% } \\
\cline { 2 - 6 } & $\mathrm{Al}^{*}$ & $\mathrm{Mn}$ & $\mathrm{Zn}$ & $\mathrm{Cu}$ & $\mathrm{Fe}$ \\
\hline $1 / 5$ & 21.5 & 80.2 & 77.6 & 79.4 & 8.2 \\
$1 / 10$ & 31.2 & 83.4 & 85.2 & 86.2 & 11.4 \\
$1 / 15$ & 36.7 & 98.2 & 94.1 & 92.1 & 14.7 \\
$1 / 20$ & 56.8 & 98.8 & 95.5 & 94.2 & 16.8 \\
\hline
\end{tabular}

$\mathrm{Al}^{*}$ calculated as gibbsite.

Table 8. Effect of grain size upon leaching efficiency of $\mathrm{Mn}$ and associated metal values (0.5 M sulfuric acid and $0.24 \mathrm{M}$ oxalic acid, $2 \mathrm{~h}, 90^{\circ} \mathrm{C}, \mathrm{S} / \mathrm{L}$ ratio $\left.1 / 15\right)$.

\begin{tabular}{cccccc}
\hline \multirow{2}{*}{ Grain Size, mesh $\mu \mathrm{m}$} & \multicolumn{3}{c}{ Leaching Efficiency, \% } \\
\cline { 2 - 6 } & $\mathrm{Al}^{*}$ & $\mathrm{Mn}$ & $\mathrm{Zn}$ & $\mathrm{Cu}$ & $\mathrm{Fe}$ \\
\hline$-60-250$ & 34.8 & 97.1 & 92.5 & 90.0 & 14.2 \\
$-80-188$ & 36.0 & 97.5 & 94.0 & 91.2 & 15.2 \\
$-120-125$ & 38.7 & 98.2 & 94.4 & 91.7 & 15.7 \\
$-170-88$ & 37.2 & 98.6 & 93.9 & 92.2 & 15.8 \\
\hline
\end{tabular}

$\mathrm{Al}^{*}$ calculated as gibbsite.

\subsubsection{Effect of Prior Reductive Roasting}

Another route for leaching Mn can be achieved by prior reductive roasting. Accordingly, two samples were roasted at $650^{\circ} \mathrm{C}$ and $850^{\circ} \mathrm{C}$ with and without $20 \% \mathrm{w} / \mathrm{w}$ oxalic followed by sulfuric acid leaching. Surprisingly, prior roasting improved the leaching efficiency of Mn even in the absence of reductant. Thus, $82 \%$ of input Mn was leached after prior roasting at $850^{\circ} \mathrm{C}$ in absence of the reductant and $96.3 \%$ in presence of the reductant. Accordingly, it can be noted that normal roasting would be advantageous for extracting $\mathrm{Mn}$ as it changes its mineral phase to more acid soluble forms. However, prior roasting has resulted in adverse effect upon the leaching efficiencies of $\mathrm{Al}, \mathrm{Cu}$, and $\mathrm{Zn}$; a matter which is most probably due to partial formation of relatively refractory oxides or ferrites of these metals.

\subsection{Potentiality of Selective Metals' Recovery}

Applying the optimum leaching conditions upon the polymetallic ore material, a suitable volume of the leach liquor was prepared to study the potentiality of recovering the leached metal values. Due to important differences in the $\mathrm{pH}$ values at which the hydroxides of the latter would precipitate, the prepared leach liquor was subjected to a selective precipitation test. However, since the difference between the $\mathrm{pH}$ values at which the hydroxides of $\mathrm{Cu}^{2+}$ and $\mathrm{Fe}^{2+}$ precipitate i.e. 5.3 and 5.5 respectively [29], it would be greatly advantageous to selectively precipitate $\mathrm{Cu}$ by cementation using metallic $\mathrm{Zn}$. The latter should be performed prior to the hydroxides of $\mathrm{Al}$ and $\mathrm{Fe}$ at $\mathrm{pH}$ values of 4.1 and 5.5 respectively. Raising the $\mathrm{pH}$ of the filtrate to 7 would result in precipitation of $\mathrm{Zn}(\mathrm{OH})_{2}$ and finally increasing the $\mathrm{pH}$ to 8.5 - 9 would lead to Mn precipitation as its hydroxide.

However, due to the lack of material in the present work, the obtained leach liquor was subjected to only two precipitation steps; namely at $\mathrm{pH} 7$ and at $\mathrm{pH} 8.5$ - 9. At the former $\mathrm{pH}$, all the $\mathrm{Al}, \mathrm{Cu}, \mathrm{Fe}$ and $\mathrm{Zn}$ would collectively precipitate leaving only $\mathrm{Mn}$ in solution which was then precipitated at $\mathrm{pH}$ value ranging from 8.5 to 9 . After filtration of the obtained $\mathrm{Mn}(\mathrm{OH})_{2}$, it was washed, dried and calcined at $1000^{\circ} \mathrm{C}$ for $1 \mathrm{~h}$. Analysis of the calcined product through XRD has indicated that the obtained diffractogram (Figure 1) matches with that of the trioxide $\mathrm{Mn}_{2} \mathrm{O}_{3}$ (ASTM card no.10 - 69). Accordingly, it has been possible to propose the flowsheet schematically shown in Figure 2 for the processing of Abu Zeneima polymetallic ore material.

\section{Conclusions}

Sulfuric acid leaching of polymetallic ore material ( $\mathrm{Al}, \mathrm{Mn}, \mathrm{Zn}$ and $\mathrm{Cu}$ ) in presence of oxalic acid as a reductant 


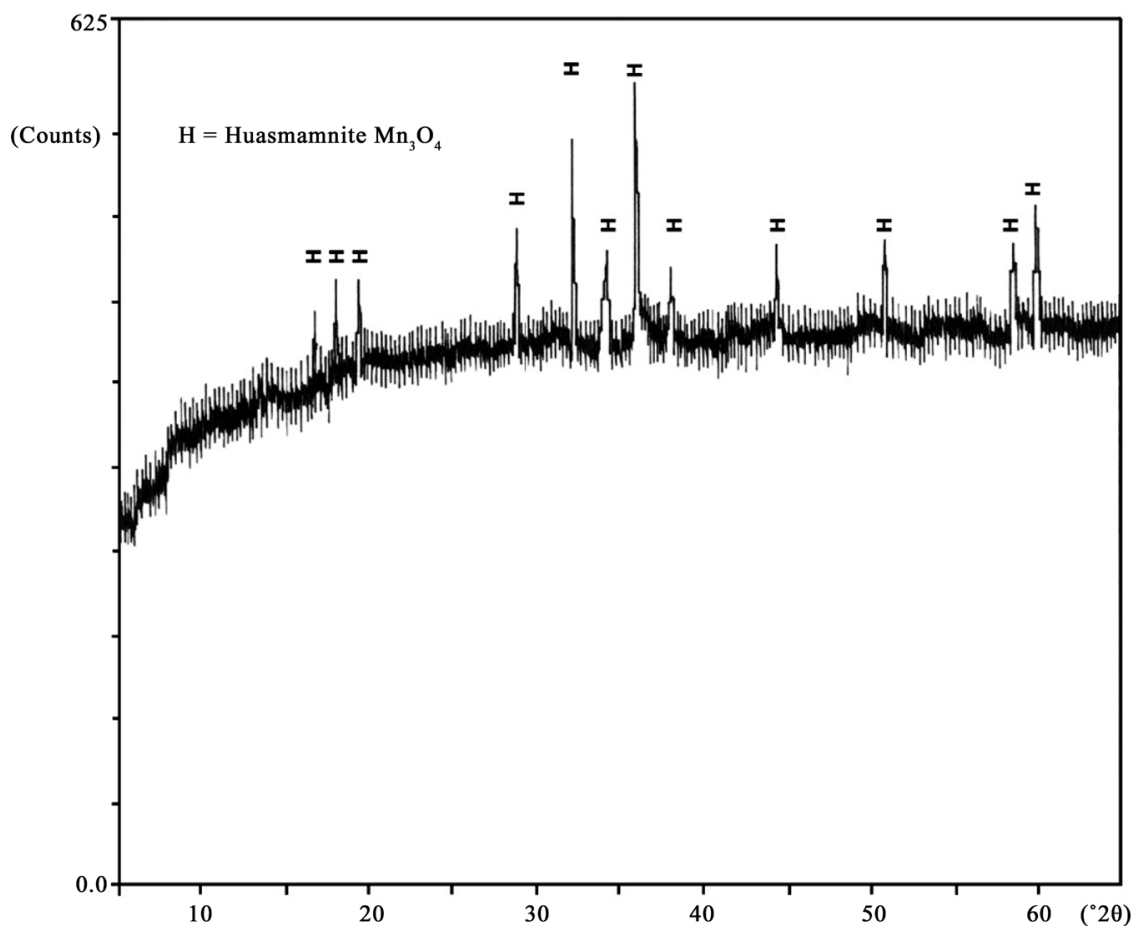

Figure 1. XRD analysis of manganese product $\mathrm{H}=$ Hausmamnite $\mathrm{Mn}_{2} \mathrm{O}_{3}$.

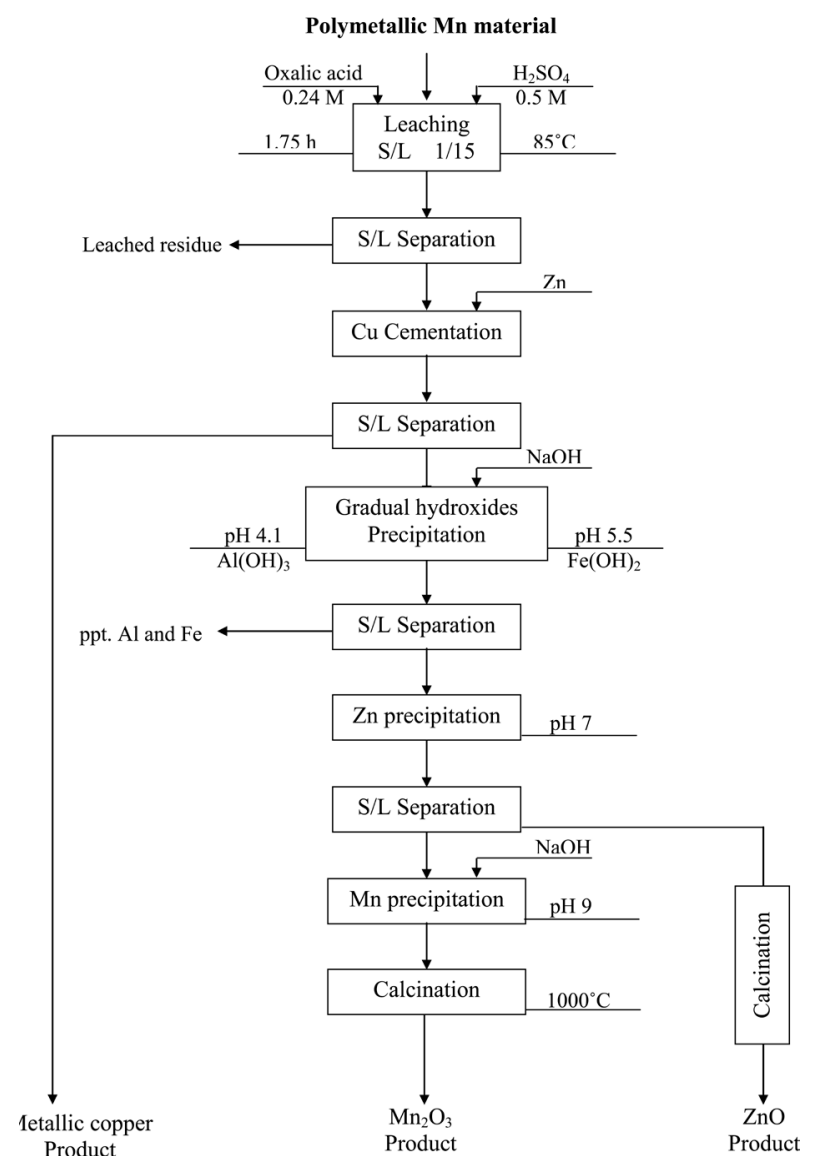

Figure 2. Proposed flowsheet for the processing of polymetallic Mn material. 
proved quite successful. The studied optimum conditions for leaching about $98 \%$ of $\mathrm{Mn}, 94 \%$ of $\mathrm{Zn}$ and $92 \%$ of $\mathrm{Cu}$ involved using $0.5 \mathrm{M}$ sulfuric acid in presence of $0.24 \mathrm{M}$ of oxalic acid for $105 \mathrm{~min}$ at $85^{\circ} \mathrm{C}$ in an $\mathrm{S} / \mathrm{L}$ ratio of $1 / 15$ and using an ore ground to less than 80 - 100 mesh size.

Selective recovery of the leached metal values can actually be achieved by alkali precipitation at different $\mathrm{pH}$ values except $\mathrm{Cu}$. The latter could be recovered by cementation using metallic $\mathrm{Zn}$ powder prior to the alkali precipitation steps.

\section{References}

[1] Sahoo, R.N. and Rao, K.S. (1989) Sulphation-Roasting of Low-Grade Manganese Ores-Optimisation by Factorial Design. International Journal of Mineral Processing, 25, 147-152. http://dx.doi.org/10.1016/0301-7516(89)90061-6

[2] Momade, F.W.Y. and Momade, Zs.G. (1999) Reductive Leaching of Manganese Oxide Ore in Aqueous MethanolSulphuric Acid Medium. Hydrometallurgy, 51, 103-113. http://dx.doi.org/10.1016/S0304-386X(98)00077-2

[3] Panda, M. and Gupta, K.N. (1988) Carbothermic Reduction of Manganese Ore by Low Temperature Carbonized Coke. NML Technical Journal, 30, 25-32.

[4] Raisoni, P.R. and Dixit, S.G. (1988) Leaching of $\mathrm{MnO}_{2}$ with Mixed Non Aqueous Solvent Dimethyl Sulfoxide. Journal of Chemical Technology and Biotechnology, 42, 167-182. http://dx.doi.org/10.1002/jctb.280420302

[5] Das, S.C., Sahoo, P.K. and Rao, P.K. (1982) Extraction of Manganese from Low-Grade Manganese Ores by $\mathrm{FeSO}_{4}$ Leaching. Hydrometallurgy, 8, 35-47. http://dx.doi.org/10.1016/0304-386X(82)90029-9

[6] Abbruzzese, C. (1990) Percolation Leaching of Manganese Ore by Aqueous Sulfur Dioxide. Hydrometallurgy, 25, 8597. http://dx.doi.org/10.1016/0304-386X(90)90066-B

[7] Abbruzzese, C., Duarte, M.Y., Paponetti, B. and Toro, L. (1990) Biological and Chemical Processing of Low-Grade Manganese Ores. Minerals Engineering, 3, 307-318. http://dx.doi.org/10.1016/0892-6875(90)90126-V

[8] Naik, P.K., Sukla, L.B. and Das, S.C. (2000) Aqueous $\mathrm{SO}_{2}$ Leaching Studies on Nishikhal Manganese Ore through Factorial Experiment. Hydromettalurgy, 54, 217-228. http://dx.doi.org/10.1016/S0304-386X(99)00075-4

[9] Jiang, T., Yang, Y.B., et al. (2003) Simultaneous Leaching of Manganese and Silver from Manganese-Silver Ores at Room Temperature. Hydrometallurgy, 69, 177-186. http://dx.doi.org/10.1016/S0304-386X(03)00033-1

[10] Jiang, T., Yang, Y.B., et al. (2004) Leaching Kinetics of Pyrolusite from Manganese-Silver Ores in the Presence of Hydrogen Peroxide. Hydrometallurgy, 72, 129-138. http://dx.doi.org/10.1016/S0304-386X(03)00136-1

[11] Chen, H.-H., Fu, C. and Zheng, D.-J. (1992) Reduction Leaching of Manganese Nodules by Nickel Matte in Hydrochloric Acid Solution. Hydrometallurgy, 28, 269-275. http://dx.doi.org/10.1016/0304-386X(92)90135-M

[12] Kanungo, S.B. (1999) Rate Process of the Reduction Leaching of Manganese Nodules in Dilute $\mathrm{HCl}$ in Presence of Pyrite: Part 1. Dissolution Behavior of Iron and Sulphur Species during Leaching. Hydrometallurgy, 52, 313-330. http://dx.doi.org/10.1016/S0304-386X(99)00023-7

[13] Kanungo, S.B. (1999) Rate Process of the Reduction Leaching of Manganese Nodules in Dilute $\mathrm{HCl}$ in Presence of Pyrite: Part 2. Leaching Behavior of Manganese. Hydrometallurgy, 52, 331-347. http://dx.doi.org/10.1016/S0304-386X(99)00022-5

[14] Das, R.P., Anand, S., Das, S.C. and Jena, P.K. (1986) Leaching of Manganese Nodules in Ammoniacal Medium Using Glucose as Reductant. Hydrometallurgy, 16, 335-344. http://dx.doi.org/10.1016/0304-386X(86)90008-3

[15] Cardwell, P.H. and Kane, W.S. (1976) Halidation of Manganese Ores to Obtain Metal Values and Recycle of Halide Values. U.S. Pat. 3992507.

[16] Kane, W.S. and Cardwell, P.H. (1974) Process for Recovering Manganese from Its Ores. U.S. Pat. 3832295.

[17] Van Peteghem, A. (1977) Extraction of Metals from Manganese Containing Nodules from the Ocean Floor. U.S. Pat. 4026773.

[18] EL Assy, I.E., et al. (1986) Report on Proving of Some Radioactive Occurrences in West Central Sinai. Int. Rep., N.M.A., Cairo.

[19] El Assy, I.E., et al. (1996) Distribution of Uranium in the Carbonate Rocks of Um Bogma Formation, South West Sinai, Egypt. 3rd Arab Conference on the Peaceful Uses of Atomic Energy, Damascus, 9-13 December 1996.

[20] Abdel Moneim, A., et al. (1997) Gibbsite, Uranium and Copper Mineralization, Um Bogma Area, South Western Sinai, Egypt. Sediments Journal of Egypt, 5, 14-18.

[21] Amer, T.E. (1997) Geochemistry and Extraction of U, Cu and Mn from the Ore Materials of the Uraniferous Paleozoic Sedimentary Rock, West Central Sinai, Egypt. Ph.D. Thesis, Cairo University, Cairo.

[22] Amer, T.E., Mahdy, M.A., El Hazek, N.T., El Bayoumi, R. and Hassanein, S. (2000) Application of Acid Pugging and Ferric Salts Leaching on West Central Sinai Uraniferous Siltstone. Proceedings of International Symposium on the 
Processing Metallurgy of Uranium, Saskatchewan, 9-15 September 2000.

[23] El Hazek, M.N, Lasheen, T.A.I. and Helal, A.S. (2006) Reductive Leaching of Manganese from Low Grade Sinai Ore in $\mathrm{HCl}$ Using $\mathrm{H}_{2} \mathrm{O}_{2}$ as Reductant. Hydrometallurgy, 84, 187-191. http://dx.doi.org/10.1016/j.hydromet.2006.05.006

[24] Lasheen, T.A., El Hazek, M.N., El Nagar, W.S. and Helal, A.S. (2007) Recovery of Mn Using Molasses as Reductant in Nitric Acid Solution. Eurasian ChemTech Journal, 9, 1-31.

[25] Shapiro, L. and Brannock, W.W. (1962) Rapid Analysis of Silicates, Carbonates and Phosphate Rocks. Revised Edition, U.S Geological Survey Bulletin, Vol. 114 A, United States Government Printing Office, Washington.

[26] Weltz, B. and Sperling, M. (1999) Atomic Absorption Spectrometry. 3rd Edition, Wiley-VCH, Weinheim, New York.

[27] Mahmoud, K.F. (2003) Simulated Heap Leaching Studies of Gattar Uranium Occurrences. Int. Rep. N.M.A., Cairo.

[28] Anon (1962) Index to the X-Ray Powder Data File. American Society for Testing Materials, West Conshohocken.

[29] Habashi, F. (1993) A Textbook of Hydrometallurgy. Métallurgie Extractive Québec, Quebec City. 